\title{
A Pelican in the Wilderness: Charles Nisbet on Pennsylvania Frontier Life
}

\author{
Jonathan Yeager \\ University of Tennessee, Chattanooga, USA
}

\begin{abstract}
This article is based on original research and analysis of multiple manuscript letters written by the Scottish Presbyterian minister Charles Nisbet (1736-1804), who emigrated to America in 1785 to become the first principal of Dickinson College in Carlisle, Pennsylvania. As an outspoken advocate for the American cause during the War of Independence, and a friend and colleague of John Witherspoon, Nisbet was the favorite choice for Benjamin Rush and the other trustees at Dickinson College. But soon after his arrival in Pennsylvania, Nisbet's relationship with Rush and the other trustees deteriorated. The new principal resented the absolute control of the trustees over the college, and quarreled with them for years about the late payments of his salary. Nisbet found America to be an overall distasteful place to live, especially for a man of letters living on the Pennsylvania frontier. Ignored by the trustees and feeling like an exile, Nisbet used his letters to lash out at the sources of his frustrations. This alleviated some of the tensions of living in America while also irritating the trustees at Dickinson College.
\end{abstract}

Keywords: Charles Nisbet, Dickinson College, Carlisle, Pennsylvania, Presbyterian, Benjamin Rush

\section{Introduction}

Psalm 102:6: I am like a Pelican of the wilderness: I am like an owl of the desert (KJV)

Derived from Psalm 102:6, the pelican became a common Christian image in the Middle Ages. Depicted as feeding its young by the blood of self-inflicted wounds to the breast, the pelican symbolized Christ's sacrifice for humanity on the cross. The Scottish immigrant and Presbyterian minister Charles Nisbet (1736-1804) saw himself as a pelican in the wilderness after he relocated to the Pennsylvania frontier to become the first principal of Dickinson College. Like the medieval pelican, Nisbet imagined himself as a type of Christ whose sufferings would lead to a greater good, in his case, the intellectual nourishment of his students. Emigrating to Carlisle in 1785, Nisbet spent the bulk of his time in Pennsylvania sulking about a new republic that did not measure up to his expectations. He found America to be made up of uncultured and unlettered citizens, and teeming with politicians of low character. Ironically, he was an outspoken supporter of America while residing in Scotland, gaining a notorious reputation for his public remarks against Britain's aggression towards the colonists. Once he moved to Pennsylvania, however, he quickly changed his mind about America. He felt lonely and isolated on the frontier, and did not think highly of the majority of people whom he

Jonathan Yeager, Ph.D., associate professor, Department of Religion and Philosophy, University of Tennessee.

Correspondence concerning this article should be addressed to 232 Holt Hall, Dept 2753, 615 McCallie Avenue, Chattanooga, TN 37403. E-mail: jonathan-yeager@utc.edu. 
met. $^{1}$ In this predicament, how would he cope with his new environment amidst the myriad of disappointments?

\section{Nisbet's Call to Dickinson College}

Charles Nisbet was born in Haddington, Scotland, on January 21, 1736. After matriculating at Edinburgh University in 1752 and taking the normal arts degree courses, he studied theology at the divinity hall for six years before graduating in 1760 and gaining a license to preach as a Presbyterian minister in the same year. ${ }^{2}$ He served at a church in Glasgow until 1764, and then took a position as an assistant pastor at Montrose, a royal burgh on the eastern coast of Scotland, until his elevation to senior minister in 1773. As a Presbyterian minister of the Kirk, Nisbet aligned himself with the so-called "Popular party", the evangelical wing of the Church of Scotland. ${ }^{3}$ Known as "the walking library", he gained a reputation for his erudition and sharp wit. ${ }^{4}$ The Scottish minister Samuel Martin of Monimail recounted a story involving his son who was on break from his studies at the University of St. Andrews. Learning that the boy was reading Homer, Nisbet proceeded to recite several lines of the book in Greek. When asked how he could possibly remember the content of such a large section in the original language, Nisbet responded "that he did not well know; that he read them, and they stuck." ${ }^{5}$ There is other evidence of his vast knowledge. When his biographer and former student Samuel Miller requested assistance on texts to reference in his Brief Retrospect of the Eighteenth Century (1803), Nisbet wrote two long letters with an extensive list of books pertaining to the most important literary contributions of the century in biblical studies, theology, literature, and science, including Latin, German, and Dutch works. ${ }^{6}$ By many accounts, Nisbet was fluent in nearly a dozen languages, depending on the source.

Importantly, Nisbet also received attention in Scotland as an outspoken supporter of America during the conflict with Great Britain. ${ }^{7}$ When Scottish ministers were called to preach fast day sermons at the time of the American War of Independence, the provocative Nisbet chose a passage from Daniel chapter 5, which depicts the finger of God writing on a wall the message of judgment—Mene, Mene, Tekel, Upharsin — to a Babylonian ruler. The implication of Nisbet's sermon was that Britain had been intoxicated by its own success and was ripe

\footnotetext{
${ }^{1}$ If we want to know the reason for Nisbet's unhappiness, we will not find the answer in the available literature on him. Despite his historical and religious significance, to date the only full length treatment of him is by his former student Samuel Miller, the later Princeton Theological Seminary professor, who wrote a sympathetic nineteenth-century memoir of his former teacher at the request of Nisbet’s family. Samuel Miller, Memoir of the Rev. Charles Nisbet, D. D., Late President of Dickinson College, Carlisle (New York: R. Carter, 1840). The best scholarship on Nisbet is by David Robson, but his specialized articles focus on the Scotsman's opinion of the French Revolution and higher education. See Robson's “Anticipating the Brethren: The Reverend Charles Nisbet Critiques the French Revolution”, The Pennsylvania Magazine of History and Biography 121 (1997), 303-28 and "Enlightening the Wilderness: Charles Nisbet's Failure at Higher Education in Post-Revolutionary Pennsylvania," History of Education Quarterly 37 (1997), 271-89.While James H. Smylie’s essay, "Second Thoughts on a Revolutionary Generation”, The Pennsylvania Magazine of History and Biography 96 (1974), 189-205, offers an overall helpful summary of Nisbet’s political and religious views, it is by no means thorough in its treatment of the disappointments he endured in America.

${ }^{2}$ Nisbet's son Alexander found among his father's papers a written declaration to become a minister, dated March 16, 1756. See Alexander Nisbet to Samuel Miller, February 11, 1806, Samuel Miller Papers, Firestone Library, Princeton University, C0277.

${ }^{3}$ On the Popular party and its opposition in the Kirk, see John R. McIntosh, Church and Theology in Enlightenment Scotland: The Popular Party, 1740-1800 (East Linton: Tuckwell Press, 1998) and Richard Sher, Church and University in the Scottish Enlightenment: The Moderate Literati of Edinburgh (Edinburgh: Edinburgh University Press, 1985).

${ }^{4}$ On Nisbet’s intellect, see Miller, Memoir of Charles Nisbet, 15-17, 28, 69-70, 313-14.

${ }^{5}$ Miller, Memoir of Charles Nisbet, 326.

${ }^{6}$ See Nisbet to Samuel Miller, December 16, 1800, in Miller, Memoir of Charles Nisbet, 267-80 and Nisbet to Samuel Miller, March 13, 1801, Samuel Miller Papers, Firestone Library, Princeton University, C0277, box 11, folder 45.

${ }^{7}$ Commenting on his support of America during the War of Independence, Nisbet told John Witherspoon that he was "almost equally obnoxious during the War.” Nisbet to John Witherspoon, April 3, 1784, Historical Society of Pennsylvania (hereafter HSP), Gratz, case 9, box 14.
} 
for a downfall. ${ }^{8}$ For his knowledge and unswerving support of America, Nisbet was rewarded with an honorary doctorate of divinity by the College of New Jersey in 1783.

In searching for a principal of Dickinson College with superior intellectual capability and attachment to America, Benjamin Rush and the other trustees could have found no better candidate than Charles Nisbet. Rush had remembered Nisbet years earlier while recruiting the Scottish Presbyterian minister John Witherspoon for the position of president of the College of New Jersey, and might have even met Nisbet while studying medicine at Edinburgh University in the late 1760s. ${ }^{9}$ When Witherspoon respectfully declined the first offer to serve at Princeton, he suggested his younger evangelical colleague Charles Nisbet as a substitute. ${ }^{10}$ Eventually, however, Witherspoon reconsidered and emigrated to America with his family in $1768 .{ }^{11}$

Witherspoon came to Princeton at a key time in American history. Under his guidance, the College of New Jersey flourished. He built up the library's holdings, raised thousands of pounds for the school, lectured on history, divinity, rhetoric, and moral philosophy, and trained students like James Madison on the merits of civic duty and common sense philosophy. ${ }^{12}$ Witherspoon also contributed to the formation of the American government, serving as a delegate for the state of New Jersey and is remembered as the only clergyman to sign the Declaration of Independence. With the success of Witherspoon as a fundraiser, statesman, and Christian leader, it is no mystery why Rush would look to Scotland once more when selecting the principal for his next collegiate venture.

Dickinson College received its charter on September 9, 1783. Rush almost singlehandedly founded the school. He corralled 40 trustees, mostly Presbyterians, to join his endeavor, strategically placing the statesman John Dickinson as the president of the board of trustees and naming the college after him in order to secure his financial patronage. Rush believed that Carlisle was the ideal location for a new institution. The town was strategically established in 1751 near the center of Pennsylvania, and already had a grammar school that could funnel students into the college. ${ }^{13}$ Rather than seeing the disadvantages of establishing a new school on the frontier, over one hundred miles away from Philadelphia and other populated areas, he argued that Dickinson College would benefit from its rural setting by drawing the nearby German community, which collectively represented the largest non-British group of immigrants in eighteenth-century America. ${ }^{14}$ Rush also assumed that with Governor John Dickinson as the president of the board of trustees, the college would be able to procure financial grants from the state. From Rush's perspective, the only thing left to do was find the right man as the principal. He immediately thought of Charles Nisbet. Rush believed that if Nisbet could offer even half the erudition and talent for raising funds as Witherspoon, Dickinson College would prosper. In a letter in

\footnotetext{
${ }^{8}$ Miller, Memoir of Charles Nisbet, 75-76.

${ }^{9}$ On Rush, see David Freeman Hawke, Benjamin Rush: Revolutionary Gadfly (Indianapolis: Bobbs-Merrill, 1971) and Donald J. D’Elia, “Benjamin Rush: Philosopher of the American Revolution,” Transactions of the American Philosophical Society 64 (1974), 1-113.

${ }^{10}$ Contemporaries of Witherspoon and Nisbet said that the two men looked alike. See Alexander Carlyle, Anecdotes and Characters of the Times, ed. James Kinsley (New York: Oxford University Press, 1973), 35.

${ }^{11}$ As a consolation prize, Rush mentioned the possibility of having Nisbet serve as a professor of languages at the College of New Jersey, but nothing came of this plan. See Benjamin Rush (hereafter BR) to John Witherspoon, August 1, 1767, in Letters of Benjamin Rush, edited by L. H. Butterfield, vol. 1 (Princeton: Princeton University Press, 1951), 45-46. See also, Miller, Memoir of Charles Nisbet, 25-27.

${ }^{12}$ On Witherspoon, see L. H. Butterfield, John Witherspoon Comes to America (Princeton: Princeton University Press, 1953) and L. Gordon Tait, The Piety of John Witherspoon: Pew, Pulpit and Public Forum (Louisville: Geneva Press, 2001).

${ }^{13}$ Judith Ridner, A Town In-Between: Carlisle, Pennsylvania, and the Early Mid-Atlantic Interior (Philadelphia: University of Pennsylvania Press, 2010), 154-57.

${ }^{14}$ Farley Grubb, “German Immigration to Pennsylvania, 1709 to 1820,” Journal of Interdisciplinary History 20 (1990), 417.
} 
April 1784, Rush informed Nisbet of his unanimous election by the trustees. ${ }^{15}$ But would he accept the offer?

Despite Nisbet's initial interest in the position, several factors delayed his move to Carlisle. Although Rush boasted of the unfettered prospects of the new college, the availability of jobs for newcomers, the integrity and acumen of the trustees, the rich soil of the landscape, and the religious orthodoxy of the townspeople, Nisbet had reason to doubt the accuracy of this information. ${ }^{16}$ British subjects like Nisbet would have known of the many difficulties that immigrants endured, including Indian attacks on the American frontier, from hearsay as well as published accounts in newspapers. ${ }^{17}$ Nisbet also might have feared the voyage across the Atlantic. Despite the many success stories of Europeans who found their way to the Middle Colonies throughout the eighteenth century, stories abounded of press gangs, pirates, diseases, and violent storms that deterred vessels headed to American ports. ${ }^{18}$ But besides the negative reports, Nisbet would have also been aware of favorable news about Pennsylvania. From the time that William Penn began promoting immigration in the early 1680s, advertisements and first-hand accounts depicted Pennsylvania as "the best poor man's country.,"19

No doubt already fretting the journey and hardships of frontier life that lay ahead, Nisbet also began to question Rush's rosy perspective of Carlisle and the college when he received a discouraging letter from John Dickinson, who advised his Scottish correspondent to reconsider the timing of his move due to recent political elections, which had the potential to undermine the new college. ${ }^{20}$ When Rush discovered what had happened, he was furious with Dickinson. He immediately penned a reassuring note to Nisbet and strong-armed Dickinson into writing a letter of apology that rescinded his former opinion. ${ }^{21}$ Once Rush had put out this fire, Nisbet gained enough confidence to pack his family and belongings aboard a ship sailing from Greenock to America, arriving at Carlisle in early July 1785.

Carlisle as a county seat was one of the most important rural towns in Pennsylvania. In the 18th century, it could be compared with other backcountry towns like Lancaster, York, Reading, and Easton, which had between 1,000 and 5,000 people. ${ }^{22}$ At the time that Nisbet emigrated to America, the population was under four million people, with about $12 \%$ coming from Scottish or Scotch-Irish descent. ${ }^{23}$ Almost as soon as they arrived, immigrants set up places of worship and formed communities largely based on ethnicity and national

\footnotetext{
${ }^{15}$ Benjamin Rush to Nisbet, April 19, 1784, in Letters of Benjamin Rush, vol. 1, 321-22.

${ }^{16}$ See Benjamin Rush to Nisbet, December 5, 1783, April 19, 1784, and August 15, 1784, in Letters of Benjamin Rush, vol. 1, 315-16, 321-25, and 334-35.

${ }^{17}$ Carlisle was a hub for refugees seeking shelter from Indian raids in the surrounding area during the French and Indian War. See William A. West, "History of the Presbytery of Carlisle, Involving the History of the Presbyteries of Donegal and Harrisburg," in The Centennial Memorial of the Presbytery of Carlisle, vol. 1 (Harrisburg: Meyers, 1889), 71-72 and Ridner, A Town In-Between, 81-83.

${ }^{18}$ See Ian Adams and Meredyth Somerville, Cargoes of Despair and Hope: Scottish Emigration to North America, 1603-1803 (Edinburgh: John Donald, 1993) and Bernard Bailyn, Voyagers to the West: A Passage in the Peopling of America on the Eve of the Revolution (New York: Vintage, 1988).

${ }^{19}$ James T. Lemon, The Best Poor Man's Country: A Geographical Study of Early Southeastern Pennsylvania (Baltimore: Johns Hopkins Press, 1972); Ned C. Landsman, "Ethnicity and National Origin among British Settlers in the Philadelphia Region: Pennsylvania Immigration in the Wake of 'Voyagers to the West'” Proceedings of the American Philosophical Society 133 (1989), 171; Hope Frances Kane, "Notes on Early Pennsylvania Promotion Literature," The Pennsylvania Magazine of History and Biography 63 (1939), 144-168.

${ }^{20}$ Charles Coleman Sellers, Dickinson College: A History (Middletown, CT: Wesleyan University Press, 1973), 64-70.

${ }^{21}$ See Benjamin Rush to Nisbet on August 27, 1784 and November 28, 1783, and Rush to John Montgomery, November 13, 1784, in Letters of Benjamin Rush, vol. 1, 335-39, 341-45.

${ }^{22}$ Lemon, The Best Poor Man's Country, 120-21.

${ }^{23}$ This estimate is based on the 1790 US census. See Campbell Gibson, "The Contribution of Immigration to the Growth and Ethnic Diversity of the American Population,” Proceedings of the American Philosophical Society 136 (1992), 169.
} 
origin. ${ }^{24}$ Since the Scots were relative latecomers to Pennsylvania, many of them felt obliged to move further west to areas beyond urban centers such as Philadelphia that were dominated by earlier settlers like the Quakers and Mennonites. ${ }^{25}$

Nisbet's entry into Carlisle was marked by a celebration among the townsfolk and the trustees. "I conceive a new sun is risen upon Pennsylvania”, Rush beamed to the merchant and college trustee John Montgomery. ${ }^{26}$ But the festivities came to an abrupt end when in the ensuing weeks, Nisbet and his family contracted a debilitating illness that left them bedridden for several weeks. Before the end of the summer, he and his family had determined to sail back to Scotland. Alerted to Nisbet's change of mind, Rush wrote to Colonel Montgomery on September 11, 1785. "It is all in vain”, Rush reported. "After using every possible argument with Dr. Nisbet that friendship, religion, or honor could dictate to prevent his returning to Scotland, I find by his letter of the fourth of this month that he is inflexible. He complains of the heat and sickness of our climate". Rush realized that there was more to this situation than the weather.

Dismal stories are propagated through our city against us from his family by the people who come from Carlisle. In one of his letters to me he talks much of our "scanty funds," and from good authority I hear of complaints which seem to indicate that his family think him disgraced and ruined by having so small a charge. They abuse, I hear, everyone that had any hand in bringing him to America, especially me. In short, my friend, we have made an unfortunate speculation in our principal. $^{27}$ ( Rush, 1785, p. 369)

Rush guessed that his family was the rudder steering the ship, telling Montgomery to look on the bright side: perhaps Dickinson College could hire an American principal at half the salary. ${ }^{28}$

In mid-October, Nisbet's decision to return to Scotland was made official when he tendered his resignation to the trustees. But while the family waited out the winter for safe passage, they reconsidered their earlier decision and now wanted to stay. The trustees agreed to reelect Nisbet on May 10, 1786, but by then, the damage was done. Nisbet resented the bill of goods that he had been sold, and Rush felt betrayed by the man he had spent so much time and energy championing to the trustees.

\section{Nisbet's Frustrations as Principal of Dickinson College}

In the years following his settlement as the principal of Dickinson College, Nisbet vented his frustration and anger the only way that he knew how, by writing letters. Dickinson's charter made no provision for the principal, or teachers of the college, to gain entrance on the school's board. Neither would the trustees welcome Nisbet's advice, especially after learning of the principal's letters in which he presented the college and town in unflattering terms to his friends in Scotland. Now living in a backwoods town, miles from any urban center and unable to contribute to a government that had already been formed by its most eminent patriots, Nisbet utilized his powers of wit to lash out in print at the sources of his disappointments. Over the course of his lifetime, this

\footnotetext{
${ }^{24}$ Daniel Snydacker, “Kinship and Community in Rural Pennsylvania, 1749-1820,” Journal of Interdisciplinary History 13 (1982), 43; Lemon, The Best Poor Man's Country, 43. Lemon shows German immigrants, for example, had strong representation in the counties of Berks, upper Philadelphia, Northampton, and York as well as the Lebanon Valley in Lancaster County. The Scotch-Irish were most visible in the Cumberland Valley and in western York County.

${ }^{25}$ Lemon, The Best Poor Man’s Country, 21.

${ }^{26}$ Benjamin Rush to John Montgomery, June 14, 1785, in Letters of Benjamin Rush, vol. 1, 357.

${ }^{27}$ Benjamin Rush to John Montgomery, September 11, 1785, in Letters of Benjamin Rush, vol. 1, 369. Lemon, The Best Poor Man's Country, 32. The average temperature at nearby Harrisburg during this time was about ten degrees warmer than London in July, and ten degrees colder in January.

${ }^{28}$ Jonathan Edwards Jr. was the leading candidate.
} 
list expanded to include, not only Rush and the Dickinson College trustees, but also the character of the American people. In his miserable condition, he was consoled by telling himself that he was fulfilling his godly duty to educate young people.

Wanting to tell his side of the story, Nisbet penned a series of letters to his friends in Scotland in order to justify his complaints. In a letter to David Erskine, the Eleventh earl of Buchan, within a few months of his resignation, Nisbet wrote "It will no doubt surprise you to learn that I am preparing to leave this country by the first opportunity. I have not been in a condition to enjoy life, or do business since I entered it.” Besides blaming the heat and fevers that he and his family had endured, Nisbet criticized the college. From his observations, teachers gave "crude and indigested" lessons and were treated by the trustees as "mere day-labourers", employed as "clerks for drawing up and signing the diplomas". The trustees had absolute control, and promoted the art of public speaking at the expense of learning. Nisbet (1785) asked his correspondent, "Will your Lordship blame me for leaving this country?"29

Even after he had determined to stay at Carlisle, Nisbet made no attempts at hiding his contempt for his new environment. In his letter to Buchan in April 1786, he complained of America's "torpid state with regard to public spirit, arts and industry", a nation "far from being united in politics". ${ }^{30}$ While submitting that some of the students showed signs of aptitude, he had low expectations for them since the seminary was governed by "ignorant Trustees". ${ }^{31}$ In a later letter, Nisbet (1787) told Buchan that Americans borrowed heavily on credit, but without any intention to pay back their loans. ${ }^{32}$ While providing an account of the formation of the Constitution in 1787, Nisbet could not help adding this comment: "Your Lordship may easily imagine how few good things can be expected to be agreed to by three Million of ignorant Peasants, under factious Leaders, and loaded with Debts at home and abroad.” Since the individual states had failed at collecting taxes and enforcing laws, Nisbet did not have high hopes that a central government could correct these problems. ${ }^{33}$ If a tax was imposed, he believed that people would simply move further west. There seemed to be few "Men of uprightness, capacity and public spirit” among the members of Congress and Americans in general. He cited the fact that a number of his personal letters had been opened, a practice that he claimed was condoned by the politicians. ${ }^{34}$

Painting the picture of America in dismal colors, Nisbet could not justify encouraging his countrymen to emigrate.

From one perspective, Nisbet had much to complain about. To begin with, Rush and the trustees had promised an annual salary of $£ 400$ and the headship of a college supposedly financially sound. Nisbet did not realize either of these promises. Between the time of his resignation and reinstatement as principal, his salary was reduced to $£ 300$. Rush justified this decision by arguing that Nisbet’s acerbic letters and bad attitude had

\footnotetext{
${ }^{29}$ Nisbet to David Erskine, December 15, 1785, in Miller, Memoir of Charles Nisbet, 139-42.

${ }^{30}$ On this head, Nisbet could have been referring to the division in politics on a national or local level. O. S. Ireland, in his article, “The Crux of Politics: Religion and Party in Pennsylvania, 1778-1789,” William and Mary Quarterly 42 (1985), 453-75, shows that Pennsylvania politics was deeply divided between the Scotch-Irish Constitutional Calvinists, who supported a state loyalty oath that targeted Quakers, Anglicans, Lutherans, and sectarians, and the more tolerant Republicans who favored moderate legislation.

${ }^{31}$ Nisbet to David Erskine, April 20, 1785, in Miller, Memoir of Charles Nisbet, 142-44.

${ }^{32}$ Nisbet to David Erskine, December 25, 1787, Waidner-Spahr Library, Dickinson College (hereafter WSL).

${ }^{33}$ Nisbet to David Erskine, September 16, 1788, WSL.

${ }^{34}$ Nisbet to David Erskine, March 20, 1790, WSL. There is evidence that Nisbet's letters had been tampered with. At the top of the first page of Nisbet to David Erskine, June 22, 1791, WSL, someone wrote, "Exaggerated account of Affairs," which is not in Nisbet's handwriting.
} 
caused harm to the school's reputation, which would lessen the number of incoming students. ${ }^{35}$ Understandably, Nisbet was not happy about a reduction in pay. Writing to John Dickinson, Rush commented,

Considering what a blow his resignation was to all our hopes and prospects...I think he should have showed some sympathy with us by offering to serve at a reduced salary till he had recovered the College and his own character to the state they were in July 1785. (Rush, 1786, p. 384) ${ }^{36}$

But even before Nisbet and the trustees forged this agreement, Rush seemed to know that the college had little chance of paying the principal's salary in full.

The school received a break in April 1786 when the state awarded it $£ 500$ and 10 thousand acres of land. This set the trend for the next 50 years, with Dickinson College relying heavily on its subsistence from the Pennsylvania legislature. At various intervals, the school received payments to help offset faculty salaries and other expenses, but the college never thrived financially, and before long Nisbet's salary was in arrears. ${ }^{37}$ In several of his letters, he fumed about the delinquency of his salary. "I have upwards of 500 pounds sterling due to me in this Country", he told Buchan in September 1788, "but as the payment of it depends on the faith of men who have shown that they have none, it cannot be reckoned for anything."38 Even when the trustees paid him, the cost of living in Carlisle had risen so dramatically in the years following his move that he had difficulty paying for goods with a stagnant income. By 1796, he noted that the price of grain and other necessities had tripled. ${ }^{39}$ Mounting debts, periodic droughts, and pests adversely affected his ability to live comfortably in America. ${ }^{40}$

Overall, the situation did not improve. Near the end of his life, he claimed that the trustees, "by their own Authority as Sovereign People”, had taken the liberty of withholding $£ 116$ from his salary and rescinding their contract with him. ${ }^{41}$ With no chance of changing their mind, it is little wonder that Nisbet took pleasure in reporting the burning of the college's newly constructed building on February 3, $1803 .{ }^{42}$ Reflecting on the recent fire in 1802 that had destroyed most of Nassau Hall, he reported to a friend with cruel irony that Dickinson College had finally succeeded in mimicking the College of New Jersey. "You must have heard that our New College was burnt to the Ground on Thursday the 3d. We had been bothered by the Trustees to make our College conform to Princeton College. We have now attained a pretty near Conformity to it, by having our Building burnt down to the Ground.” Nisbet saw justice in this event since the plan for the building had been "founded on Fraud and Knavery". According to him, in order to pay for the structure, the trustees had utilized money set aside for the professors and in the process had "cheated your humble servant out of 2670 dollars, the interest of my arrears, and diminished my yearly salary more than 80 pounds sterling.” In Nisbet's mind, this "Visitation of Divine Providence" had balanced the scale with the trustees, though he had little hope that they

\footnotetext{
${ }^{35}$ Benjamin Rush to John Montgomery, November 28, 1785, in Letters of Benjamin Rush, vol. 1, 376.

${ }^{36}$ Benjamin Rush to John Dickinson, April 4, 1786, in Letters of Benjamin Rush, vol. 1, 384.

${ }^{37}$ Sellers, Dickinson College, 91, 109-11. See also Nisbet to the Executive Council of Pennsylvania, October 16, 1787, HSP, Gratz, case 7, box 15 .

${ }^{38}$ Nisbet to David Erskine, September 16, 1788, WSL.

${ }^{39}$ Nisbet to Alexander Addison, April 25, 1796, Alexander Addison Papers, 1786-1803, Darlington Collection, University of Pittsburgh, DAR 1925.06 (hereafter UPitt), box 1, folder 58. Nisbet's comments are consistent with the rising cost of living reported in other nearby regions. In Lancaster County, for instance, the price of land had risen tenfold from the 1730s to the end of the 1780s. See Lemon, The Best Poor Man's Country, 87-96.

${ }^{40}$ In his letters to Addison on December 3, 1796 and January 31, 1797, Nisbet comments on the droughts and the damage done by the Hessian fly. See UPitt, box 1, folders 61 and 62.

${ }^{41}$ Nisbet to William Young, December 10, 1801, WSL.

${ }^{42}$ Ridner, A Town In-Between, 186-87.
} 
would realize how badly they had mistreated him over the years. ${ }^{43}$ Not until after he had died, did Nisbet's family receive the amount owed to him, which Miller said came only by way of legal action. ${ }^{44}$

Besides fretting about his finances, Nisbet spent many hours stewing over what he considered to be a low state of learning at Dickinson College. During his time as principal, students grumbled about his "prelection” method, which required them to take detailed notes of his lectures verbatim. Many of the students were in a hurry to earn their degrees in the shortest time possible, resisting Nisbet's dictum that a worthy education could only come by way of reading multiple texts and by careful study over several years. He (1791) grumbled to Buchan that "A few Scraps from Voltaire, Montesquieu, Hume and Rousseau, are reckoned a complete Education here." ${ }^{\text {} 45}$ Since students could abandon their education at any point, recognizing that a college degree was not necessary in most cases for gainful employment, Nisbet had very little power to enforce his ideology at Dickinson. ${ }^{46}$

He particularly resented the trustees' preference for public speaking, firmly believing that hours of practicing speeches cheated students from appropriating ideas through books. ${ }^{47}$ How could young people deliver discourses on subjects that they knew nothing about? On this point, he did not present Dickinson College as uniquely deficient. He counted most American colleges, including Harvard, Dartmouth, King's College (Columbia), the College of New Jersey, the University of Pennsylvania, the College of Rhode Island (Brown), and Yale as guilty of fostering the same kind of unlearned atmosphere. Nisbet (1792) perceived that Americans sought to produce colleges where "Simplification, Brevity and a superficial Knowledge of things" is taught, "so that their Students are Jack of all trades, and Masters of none at all." ${ }^{48}$ He expressed shame in an educational system that paled by comparison to the European model that he had grown to idolize.

For their part, the students at Dickinson felt overwhelmed by the educational demands of the trustees and Nisbet. Realizing that their fees kept the college from bankruptcy, the students rebelled in the 1790s, lobbying for quick degrees that did not depend on the prelection system. In 1798, they pressed the trustees for the right to graduate in one year. Nisbet vehemently opposed this kind of "literary quackery", but since his vote did not count, he had little choice but to acquiesce to the new provision. ${ }^{49}$ Had the trustees resolved not to give in to these demands, the school's reputation might have been saved. In the subsequent years, enrollment dropped considerably as parents and students alike pondered the value of an education that could be earned in one year by comparison to the typical three-year granting institutions at Princeton and elsewhere. ${ }^{50}$

Psychologically, Nisbet felt alone during his time in America, remembering more favorable times in Scotland where genuine friends seemed to abound. Even his fellow Scotsmen did not measure up once they had become Americanized. "I find nobody here like the friends of my youth and my mature age in Scotland," he told Charles Wallace. "A stranger will meet with a great deal of civility at first, but this soon gives place to

\footnotetext{
${ }^{43}$ Nisbet to Alexander Addison, February 12, 1803, UPitt, box 1, folder 86.

${ }^{44}$ Miller, Memoir of Charles Nisbet, 287. In a footnote to a letter from Benjamin Rush to John Montgomery on February 9, 1804, Butterfield states that a settlement of \$7,000 was reached with Nisbet’s heirs. See Letters of Benjamin Rush, vol. 2, 878.

${ }^{45}$ Nisbet to David Erskine, June 22, 1791, WSL.

${ }^{46}$ Nisbet to Ashbel Green, August 5, 1793, HSP, Dreer American Clergy.

${ }^{47}$ Before moving to Carlisle, Nisbet had received a copy of the charter which granted the trustees exclusive control over the college, but he was led to believe that the bylaws were not set in stone. See Robson, "Enlightening the Wilderness," 275-77.

${ }^{48}$ Nisbet to Alexander Addison, May 11, 1792, UPitt, box 1, folder 42. In another letter, he described the leadership of most American seminaries as "Goths and Vandals." CN to DE, March 20, 1790, WSL.

${ }^{49}$ Miller, Memoir of Charles Nisbet, 283.

${ }^{50}$ Robson, “Enlightening the Wilderness,” 281-82.
} 
coldness and indifference. I cannot say that I have acquired a friend on this Continent, though. I have sundry well wishers, especially among my countrymen.” ${ }^{51}$ Nisbet's perception of himself was as an outsider. Whereas in Scotland he had gained a notorious reputation for his pro-American stance, now living on the frontier, he had become something even worse: a nobody. ${ }^{52}$ He furthermore felt deserted since very few of his Scottish friends wrote to him. His distance to America's coastal cities made letter-writing a challenge for authors and recipients. Reflecting on his predicament, he portrayed himself as a "Pelican in the Wilderness" ${ }^{53}$

Rush and the other trustees had not anticipated hiring a derisive, solitary bird to make its nest at Dickinson College. Yet, by Nisbet's own admission, he had always been an alien in a foreign land. While known as an outspoken advocate of the American cause and an unswerving Calvinist in Scotland, he remained on the fringe, even when counted among the evangelicals associated with the Popular Party in the Church of Scotland. ${ }^{54}$ After relocating to America, his communications with the friends of his youth became more sporadic. He received regular updates from the Edinburgh Presbyterian minister John Erskine, but other evangelicals in the Kirk, such as Thomas Randall Davidson, showed little effort in making contact with him. In a letter in 1797 to one of his few Scottish correspondents, Nisbet said that he did not blame his friends in Scotland for losing touch with him, especially since he had been gone for so long. Sizing up his current situation, he concluded that,

on the whole, I was much better off among you than I can be here, because altho' I was not popular myself, my Friends were popular, and I was of the Popular Party, which led me to imagine that I shared in the popularity of my friends, and was certainly better treated on their Account. Whereas here I have no Man like-minded, and consequently are neither in the majority nor in the minority. (Nisbet, 1797) ${ }^{55}$

Analyzing Nisbet's letters, it becomes apparent that his many complaints were therapeutic for him. Ignored by the trustees, debt-ridden, living on the outskirts of society, and feeling deprived of genuine friendship, he had significant pent-up frustrations that needed to be released. The America that Rush and others had promised him clearly fell short of his expectations. With no real power within the college, he remedied the situation by funneling his grievances into caustic written words that seemed to ease the pressure. Not many of his recipients could suffer Nisbet's imprudent remarks, which is presumably why he maintained very few regular correspondences. Asked by Samuel Miller in his old age to provide some thoughts on his Presbyterian colleague, the former president of the College of New Jersey, Ashbel Green wrote that Nisbet's wit tended to gush out, uncontrollably. "Too often for his own quiet, it was satirical, or sarcastic; causing loss of friendship in some who could not make allowance for an overbearing propensity" (Green, 1839). ${ }^{56}$ The Scottish philologist John Jamieson said something similar. He told Miller that he counted Nisbet as a close friend, but could hardly stand reading his letters, which were saturated with sarcasm and unrestrained complaints. According to Jamieson (1805), Nisbet "had such an irresistible desire of saying smart things, that he seldom let any opportunity of doing so pass, at whatever expense" ${ }^{57}$ Nisbet's apparent failure to tone down his remarks gave offense to many of his correspondents. Only certain people—and mostly Scotsmen—were willing to overlook

\footnotetext{
${ }^{51}$ Nisbet to Charles Wallace, September 2, 1790, Miscellaneous Personal Name File, New York Public Library (hereafter NYPL).

${ }^{52}$ See Nisbet to Ashbel Green on August 5, 1793, HSP, Dreer American Clergy.

${ }^{53}$ Nisbet to Charles Wallace, August 19, 1791, NYPL.

${ }^{54}$ Nisbet to Alexander Addison, September 29, 1791, UPitt, box 1, folder 38.

${ }^{55}$ Nisbet to Charles Wallace, June 2, 1797, NYPL.

${ }^{56}$ AshbelGreen to Samuel Miller, April 30, 1839, in Miller, Memoir of Charles Nisbet, 314.

${ }^{57}$ John Jamieson to Samuel Miller, August 5, 1805, HSP, British Literary Miscellany, Case 11, Box 7.
} 
his voracious wit, but not always without some admonishment.

Nisbet sought to explain his perceived sour attitude. In an important letter to Lord Buchan in June 1791, Nisbet apologized for his abrasive remarks while revealing his true intentions. "I acknowledge that I am apt to complain," he submitted, "especially when separated so far from my friends, but all I ever meant by it was to lessen my griefs by communication, and not to give trouble [to] my friends. ${ }^{, 58} \mathrm{His}$ phrase of wanting to "lessen my griefs by communication”, is particularly telling as it provides a hint on why he exercised little restraint in his letters: It was the best option he had for mitigating his circumstances.

\section{Conclusion}

If Nisbet was so unhappy in America, why did he choose to stay? There were several factors which deterred him from returning to Scotland. Although in the early years of his time at Carlisle, he considered moving back to his homeland, his friends in Scotland convinced him that he would have a greater impact as the principal of Dickinson College than as a Presbyterian clergyman in the Kirk. ${ }^{59}$ By the 1790s, his family had settled into a new life in America. His daughters Mary and Alison had married local men and began raising children. Furthermore, as he grew older, he struggled to perform all his duties, and assumed that he would have trouble securing a patron in Scotland willing to present him to a living. ${ }^{60}$

But more practically, Nisbet felt it his duty to remain in America for no other reason than to train future generations. While describing his position at Carlisle in bleak terms to Lord Buchan in 1790, Nisbet took solace that despite his problems he was fulfilling a divinely sanctioned role.

My Affairs are still in a bad State and there is no prospect of any amendment of them. I struggle against the stream, but with little effect. I have been supported almost by miracle, and do my duty in the best manner I can... This is hard, but as God is pleased to give me health, I must struggle with my bad fortune as well as I can. (Nisbet, 1790) ${ }^{61}$

This same self-sacrificing spirit is evident in a letter to Charles Wallace in the following year. He wrote to his Scottish friend that,

It is indeed a new world in many respects, and I have learned by disappointments to practise much self-denial in it, and to be content with few enjoyments. I live in a great measure out of society, and have now almost as few correspondents as visitors, but while I have health, and common comforts of life, and a consciousness that I am not altogether useless to mankind, I must be content. (Nisbet, 1791) ${ }^{62}$

Despite the dim outlook, he believed that he could do some good through his influence as a teacher. ${ }^{63} \mathrm{He}$ vowed to "live among my books and in the exercise of my Duty". ${ }^{64}$ Positioning himself as a Christian martyr, Nisbet thought that perhaps he could make the best of the situation and focus his attention on training the students at Dickinson College. ${ }^{65}$

When considering Nisbet's personality, the context of his life, and the content of his letters we can see why he lashed out in written words. Feeling exiled, unappreciated, and living in what he considered as a

\footnotetext{
${ }^{58}$ Nisbet to David Erskine, June 22, 1791, WSL.

${ }^{59}$ See John Erskine to Nisbet, July 28, 1786, in Miller, Memoir of Charles Nisbet, 147.

${ }^{60}$ Nisbet to Charles Wallace, October 25, 1798, NYPL.

${ }^{61}$ Nisbet to David Erskine, March 20, 1790, WSL.

${ }^{62}$ Nisbet to Charles Wallace, August 19, 1791, NYPL.

${ }^{63}$ See Nisbet to Charles Wallace, May 18, 1797, NYPL.

${ }^{64}$ Nisbet to Charles Wallace, August 19, 1791, NYPL.

${ }^{65}$ Besides Samuel Miller, Nisbet also instructed the future Chief Justice of the Supreme Court, Roger Brooke Taney.
} 
vice-ridden, uncultured society, he transferred his frustrations onto the pages of his letters for the simple reason that he found this outlet consoling, allowing him to release the bitterness that had built up from his unenviable circumstances. While aware of the hardships that awaited immigrants in America, he nevertheless miscalculated the effect that the frontier would have on him. He might have assumed a certain amount of difficulties accompanying his life on the frontier, but he had not expected to be principal of a college in which he would have virtually no say in its governance. In order to ease his predicament, he took to letter-writing. Whereas his enemies could bar his entrance onto the board of trustees, reduce his salary, and flout his counsel, they could not control what he wrote to his correspondents. With what good graces he had left, he made the most of his situation by channeling his energy toward straining the next generation of Americans. He had become a pelican in the wilderness, determined that his wounds would provide nourishment for the young.

\section{References}

Adams, I, \& Somerville, M. (1993). Cargoes of despair and hope: Scottish emigration to North America, 1603-1803. Edinburgh: John Donald.

Bailyn, B. (1988). Voyagers to the West: A passage in the peopling of America on the eve of the revolution. New York: Vintage.

Butterfield, L. H. (1953). John Witherspoon comes to America. Princeton: Princeton University Press.

Butterfield, L. H. (Ed.). (1951) Letters of Benjamin Rush (Vol. 1). Princeton: Princeton University Press.

Butterfield, L. H. (Ed.). (1951). Letters of Benjamin Rush (Vol. 2). Princeton: Princeton University Press.

Carlyle, A. (1973). Anecdotes and Characters of the times. J. Kinsley, (Ed.). New York: Oxford University Press.

D’Elia, D. J. (1974). Benjamin Rush: Philosopher of the American Revolution. Transactions of the American Philosophical Society, 64, 1-113.

Ferguson, G. (1959). Signs \& symbols in Christian art. New York: Oxford University Press.

Gibson, C. (1992). The contribution of immigration to the growth and ethnic diversity of the American population. Proceedings of the American Philosophical Society, 136, 169.

Grubb, F. (1990). German immigration to Pennsylvania, 1709 to 1820. Journal of Interdisciplinary History, $20,417$.

Hawke, D. F. (1971). Benjamin Rush: Revolutionary gadfly. Indianapolis: Bobbs-Merrill.

Ireland, O. S. (1985). The crux of politics: Religion and party in Pennsylvania, 1778-1789. William and Mary Quarterly, 42, 453-475.

Kane, F. (1939). Notes on early Pennsylvania promotion literature. The Pennsylvania Magazine of History and Biography, 63, 144-168.

Landsman, N. C. (1989). Ethnicity and national origin among British settlers in the Philadelphia region: Pennsylvania immigration in the wake of "Voyagers to the West". Proceedings of the American Philosophical Society, 133, 171.

Lemon, J. T. (1972). The best poor man's country: A geographical study of early southeastern Pennsylvania. Baltimore: Johns Hopkins Press.

McIntosh, J. R. (1998). Church and theology in enlightenment Scotland: The Popular Party, 1740-1800. East Linton: Tuckwell Press.

Miller, S. (1840). Memoir of Charles Nisbet. New York: R. Carter.

Ridner, J. (2010). A town in-between: Carlisle, Pennsylvania, and the early mid-Atlantic interior. Philadelphia: University of Pennsylvania Press.

Robson, D. (1997) Enlightening the wilderness: Charles Nisbet's failure at higher education in post-Revolutionary. Pennsylvania History of Education Quarterly, 37, 271-289.

Robson, D. (1997). Anticipating the brethren: The reverend Charles Nisbet critiques the French Revolution. The Pennsylvania Magazine of History and Biography, 121, 303-328.

Sellers, C. C. (1973). Dickinson College: A history. Middletown, CT: Wesleyan University Press.

Sher, R. (1985). Church and university in the Scottish enlightenment: The moderate literati of Edinburgh. Edinburgh: Edinburgh University Press.

Smylie, J. H. (1974). Second thoughts on a revolutionary generation. The Pennsylvania Magazine of History and Biography, 96, 189-205. 
Snydacker, D. (1982). Kinship and community in rural Pennsylvania, 1749-1820. Journal of Interdisciplinary History, $13,43$. Tait, L, G. (2001). The piety of John Witherspoon: Pew, pulpit and public forum. Louisville: Geneva Press.

Twining, L. (1885). Symbols and emblems of early mediaeval Christian art. London: J. Murray.

West, W. A. (1889). History of the presbytery of Carlisle, involving the history of the presbyteries of Donegal and Harrisburg. In

H. Meyers (Ed.), The centennial memorial of the presbytery of Carlisle (Vol. 1, pp. 71-72). Harrisburg: Meyers House. White, T. H. (2002). The book of beasts: Being translation from a Latin bestiary of the twelfth century. Madison: Parallel Press. 